\title{
Лексема шиг ‘время’ и вопросы грамматикализации в тувинском языке
}

\section{Людмила А. Шамина}

Институт филологии Сибирского отделения Российской академии наук, Российская Федерация

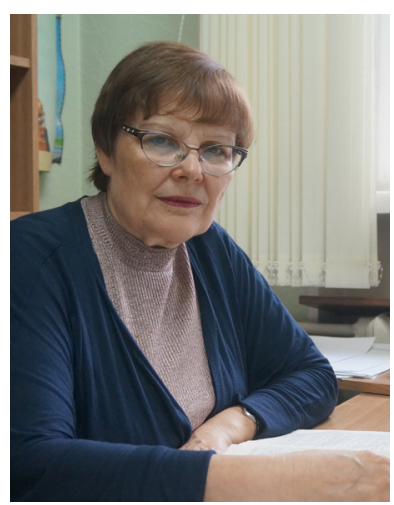

В статье представлен анализ семантики и функиионирования грамматикализованных структур с лексемой шаг - 'время' в тувинском языке. На фоне имеющихся исследований, посвященных проблемам грамматикализации элементов разных уровней тувинского языка (фонетика, лексика, грамматика), специальное исследование структуры, семантики и функционирования грамматикализованных единиц, создание классификационных схем для таких языковых единиц пока отсутствует.

Цель данной статьи - описание нового коммуникативного поведения лексем в условиях культурной адаптации, обеспечивщей выполнение ими вновь возникающих функций.

Исследуются новые слова, значения слов, новые морфосинтаксические конструкции и новые значения существующих морфосинтаксических конструкций тувинского языка, которые добавились к уже имеющейся кодифицированной системе коммуникации. Для изучения проблемы были привлечены материалы из художественной литературы на тувинском языке, примеры из словарей и грамматик и полевые материалы, полученные автором во время экспедиций в Тувинскую АССР.

В результате исследования была выявлена основная тенденция грамматикализации причастно-послеложных конструкций тувинского языка с темпоральными лексемами шаг - 'время', үе - 'время': фразеологизация некоторого набора слов, позволяющая стать регулярно воспроизводимым либо зачалом в фольклорном повествовании, либо концовкой предложения.

Результаты исследования вносят вклад в развитие теории грамматикализации, вписывая материалы тувинского языка в группу языков, в которых данное явление уже исследовано.

Ключевые слова: лексика; семантика; грамматикализация; фразеологизация; причастно-послеложная конструкция; тувинский язык; послелог; вводное слово; устойчивая синтаксическая структура

\section{Для цитирования:}

Шамина Л. А. Лексема шаг 'время' и вопросы грамматикализации в тувинском языке [Электронный ресурс]// Новые исследования Тувы. 2019, № 2. URL: https://nit.tuva.asia/nit/article/view/856 (дата обращения: дд.мм.гг.). DOI: 10.25178/nit.2019.2.16

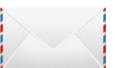

Шамина Людмила Алексеевна - доктор филологических наук, главный научный сотрудник сектора языков народов Сибири, Института филологии Сибирского отделения Российской академии наук. Адрес: 630090, Россия, г. Новосибирск, ул. Николаева, д. 8. Тел.: +7 (383) 330-15-18. Эл. адрес: Shamina_la@mail.ru ORCID ID: 0000-0003-0539-7732

Shamina Lyudmila Alekseevna, Doctor of Philology, Chief Research Fellow, Sector of languages of the peoples of Siberia, Institute of Philology, Siberian branch, Russian Academy of Sciences. Postal address: 8 Nikolaev St., 630090 Novosibirsk, Russian Federation. Tel.: +7 (383) 330-15-18. E-mail: Shamina_la@mail.ru 


\title{
The lexeme shag ('time') and the issues of grammatization in Tuvan language
}

\author{
Lyudmila A. Shamina \\ Institute of Philology, Siberian Branch, Russian Academy of Sciences, Russian Federation
}

\begin{abstract}
The article analyzes the semantics and function of grammatized structures featuring the lexeme 'shag'(time) in Tuvan language. While a number of studies have dealt with grammatization on various levels of Tuvan language, such as phonetics, vocabulary or grammar, there is still no in-depth study of structure, semantics and function of grammatized structures, and a classification framework for such linguistic units is also missing.

This article aims to provide a description of a new communicative behavior of lexemes functioning under cultural adaptation, which in turn has enabled them to perform the new functions/

We have studied new words, meanings and morphosyntactic constructions, as well as new roles of existing morphosyntactic constructions in Tuvan which have been added to the existing system of communication. To study the issue, we have used samples from Tuvan literature, dictionaries and grammar books, as well as field materials collected by the author on her expeditions to Tuvan ASSR.

The outcomes of the study has allowed us to single out the main trend in grammatization of participial postfix constructions containing temporal lexemes 'shag' and ' $y e$ ' (time). The trend lies in phraseologization of a certain wordset which allows it to become a regularly reproduced element or a starting element in a folklore narrative, or be used at the ending of a sentence.

The conclusions contribute to the theory of grammatization by adding Tuvan linguistic material to that of the language group where the corresponding features have been already studied.
\end{abstract}

Keywords: vocabulary; semantics; grammatization; phraseologization; participial postfix construction; Tuvan language; postfix; parenthetical construction; fixed syntactic structure

\section{For citation:}

Shamina L. A. The lexeme shag ('time') and the issues of grammatization in Tuvan language. The New Research of Tuva. 2019, № 2 [online] Available at: https://nit.tuva.asia/nit/article/view/856 (access date ... ). DOI: 10.25178/nit.2019.2.16

\section{Введение}

Теория грамматикализации за последние десятилетия стала неотъемлемой составляющей в исследованиях по языкам мира, в которых освещается и интерпретируется структура особых типов грамматикализованных конструкций. О явлении грамматикализации ${ }^{1}$ лингвисты думали и писали на протяжении многих веков «в том числе задолго до появления самого термина “грамматикализация”» (обзор работ см.: Майсак, 2005: 23-36). Независимо от употребления этого термина вопросы развития грамматических показателей обсуждались в работах лингвистов 1960-1970-х гг. (Аналитические конструкции ... , 1965; Курилович Е., 1965; Касевич, 1988). В исследованиях разных периодов подчеркивается мысль, что основной причиной превращения лексических значений в грамматические является, во-первых, переосмысление имевшегося ранее материала, а во-вторых, ослабление лексического значения и преобладание грамматического компонента у исследуемого объекта.

На фоне немалого количества исследований, посвященных проблемам грамматикализации элементов разных уровней языка (фонетика, лексика, грамматика), в тувиноведении на сегодняшний день постановка проблемы в такой формулировке не нашла своего отражения в имеющихся публикациях. Крат-

\footnotetext{
${ }^{1}$ Грамматикализация - процесс, в ходе которого лексические единицы и конструкции приобретают грамматические функции и затем продолжают развивать новые грамматические функции) (Майсак, 2005: 37-82). Например, полнозначный глагол со значением 'стать' может преобразоваться в маркер будущего времени или указательное местоимение может превратиться в определенный артикль.
} 
ко представленные грамматикализованные структуры в «Грамматике тувинского языка ...» (Исхаков, Пальмбах, 1962), в работах Ш. Ч. Сата, Д. А. Монгуша, Т. А. Майсака, а также автора данной статьи (Сат, 1955, Монгуш, 1963; Майсак, 2005; Шамина, 2016) показывают острую необходимость обратить внимание исследователей на процессы, в которых сложные ментальные репрезентации дают старт образованию их нового коммуникативного поведения в условиях культурной адаптации и обеспечивают выполнение вновь возникающих функций. Таким образом, необходимость написания нашей статьи обусловлена тем, что в тувиноведении не существует обобщающих работ по данной тематике.

Исследуя грамматикализованные структуры тувинского языка, мы рассматриваем грамматикализацию как средство «оформления грамматической структуры, существующей независимо от самого процесса грамматикализации (Гращенков, 2015: 16).

Современные синтаксические теории, мир которых, как отмечает Я. Г. Тестелец, «совершенно необозрим» (Тестелец, 2001: 28), помогают объяснить правила внутренней организации, взаимодействия с внешним контекстом и интерпретации исследуемых тувинских конструкций, определить их место в грамматической системе тюркских языков. Установка на объяснение, содержательный семантический анализ синтаксических явлений и др. элементы активно развивающегося направления лингвистического анализа - «Грамматики конструкций» (обзор работ см.: Рахилина, Плунгян, 2011), - позволяет представить синтаксическую картину многих языковых фактов и находит прямые параллели в российской лингвистической традиции (Шведова, 1960; Русская грамматика, 1980; Арутюнова, 1976; Белошапкова, 1977; Черемисина, 1979; Предиктивное склонение ..., 1984; Структурные типы ..., 1986 и др.).

Целью данной статьи является исследование нового коммуникативного поведения лексем тувинского языка в условиях культурной адаптации, обеспечившей выполнение ими вновь возникающих функций.

Источниковой базой исследования стали тексты тувинского фольклора, опубликованные в сборниках (Алдай-Буучу, 1993; Аксагалдай ашак: тыва хуулгаазын тоолдар, 1992; Сарыкай, 1982, 1985; Даржай, 1994; С. Тамба, 1984; Бокту-Кириш, Бора-Шээлей: Тыва улустуң маадырлыг тоолу, 1995; Тыва улустуң тоолдары, 2012), примеры из словарей (Тувинско-русский словарь,1955; Тувинско-русский словарь,1968; Русско-тувинский словарь 1963; Русско-тувинский словарь, 1980) и грамматики (Грамматика тувинского языка, 1961), многотомной серии «Памятники фольклора народов Сибири и Дальнего Востока» (Памятники ..., 2010), а также полевые материалы, полученные автором во время экспедиций и командировок в Тувинскую АССР (1980, 1981-1985 гг. Полевые материалы хранятся в Институте филологии Сибирского отделения РАН). В статье также использованы фольклорные тексты «Электронного корпуса текстов тувинского языка», разработанного группой филологов Тувинского государственного университета (Научно-образовательный центр «Тюркология») под руководством М. В. Бавуу-Сюрюн.

\section{Изменение морфосинтаксического статуса полнозначных лексем как результат процесса грамматикализации}

Развитие морфосинтаксической структуры, выполняющей коммуникативные функции, происходит в языке преимущественно через диахронию (исторические изменения) (Гивон, 2015: 97), предполагающую рассмотрение индивидуальных инноваций и их социальное распространение как неотъемлемую часть истории культуры. В грамматической диахронии морфосинтаксические структуры возникают и исчезают, «и затем возникают снова, заново кодируя - часто при помощи новых морфосинтаксических средств - те же самые коммуникативные функции» (там же: 102). Утрата старых грамматических структур и реграмматикализация происходит постепенно. Т. Гивон отмечает, что новые слова, значения слов, новые морфосинтаксические конструкции и новые значения существующих морфосинтаксических конструкций постепенно добавляются к уже имеющейся кодифицированной системе коммуникации (там же).

Одним из путей грамматикализации моделей бипредикативной конструкции (БПК) является фразеологизация полнозначной предикативной единицы (ПЕ), утрата ею самостоятельного значения и превращение в особое модальное средство оформления высказывания. Поясним, что под моделью БПК понимаем модель объединения двух предикативных единиц (ПЕ). Это отдельная языковая единица, планом содержания которой является некоторое смысловое отношение между событиями действительности; планом выражения - определенная схема соединения ПЕ (Структурные типы ..., 1986: 23). Показатель связи, оформляя зависимую предикативную единицу (ЗПЕ), является конструктивным центром модели, и выражает ее синтаксическую семантику (Черемисина, 1979: 13-20). Наблюдается определенная связь между структурой зависимой предикативной единицы ЗПЕ и семантикой выражаемых ею отношений. 


\section{THE NEW RESEARCH OF TUVA}

В тувинском языке примерами такого рода служат формы причастия будущего времени на $=p$ в дательном падеже. На базе этой полифункциональной формы, выражающей, прежде всего, значение общей временной соотнесенности, а также некоторые из значений блока обусловленности, развились значения оценки представления о событии потенциальном, оценка способности субъекта, черты его характера (ср.: бодаарга - 'как подумаешь', минниирге - ‘признавать' и пр.).

(1) Бир-бир бодаарымга, улус-чонга «думчуун сукпас чери чок» деп чемеледи-даа берги дег (Даржай, 1994: $114)^{1}$.

$\begin{array}{lllll}\begin{array}{l}\text { бир=бир } \\ \text { порой }\end{array} & \text { бода=ар=ым=га } & \text { улус-чон=га } & \text { думчу=ун } & \text { сук=пас } \\ & \text { думать=PrP=1SG=DAT } & \text { народ=DAT } & \text { нос=ACC } & \text { совать=NEGPrP } \\ \text { чер=и } & \text { чок } & \text { деп } & \text { чемеле=д=и.даa } & \text { бер=ги.дег } \\ \text { место=POSS.3S } & \text { нет } & \text { CONJ } & \text { упрекать=CAUS=CV.PRTCL } & \text { AUX=POT }\end{array}$

Перевод: ‘Порою мне думается, что его могут упрекнуть: «Куда не надо нос суешь»'.

\section{Превращение лексических единиц темпоральной семантики в грамматические единицы}

Пространственно-временные представления, вырабатываемые языковым сознанием, участвуют в конструировании в рамках каждой культуры своей особой модели мира. Время, как и пространство, относится к базовым категориям человеческого мышления, в явном или скрытом виде присущим любому типу дискурса. Язык проявляет избирательность в кодировании тех или иных отношений наиболее грамматикализованными средствами (падежными и иными формами имен, служебными словами, временными предикатами и формируемыми ими конструкциями).

Тувинский язык располагает значительным количеством грамматических средств выражения временных отношений: локальные падежи, релятивные слова различных разрядов (послелоги, служебные имена, наречия). Мы, однако, сконцентрируемся только на употреблении слова шаг - 'время' в самостоятельном и служебном употреблении.

Самостоятельное употребление слова шаг. В тувинско-русском словаре (Тувинско-русский словарь, 1968: 653) шаг переводится как 'время': ол шагда - 'в те времена': хостуг шаг (үе) - 'свободное время'; бурунгу шагда - 'в древние времена'; тарылга үези - 'время сева'. Производные от шаг: шагда - 'давно', шаанда - 'давно', шаандакы (шаандагы) - 'давнишний'.

В эпическом тексте слово шаг способствует целостному восприятию художественной действительности, композиционно организует произведение. Предложения начинаются с традиционных шак оон бээрле - 'именно с тех пор', шак ынчаар - ‘именно так’2. Ср.: Эрте-бурунгу шагда (Алдай-Буучу, 1993: 250) 'Прежде раннего времени’; Эртенги бурунгу шагда (Тыва улустуң ..., 2012: 155) - 'Прежде завтрашнего времени’. В фольклорных текстах оно имеет значение 'давнее время'.

(2) Шаг шаа-биле турбас, чавылдак көгү-биле турбас (Тувинско-русский словарь, 1968: 563).

$\begin{array}{llllll}\text { шаг } & \text { шаа-биле } & \text { тур=бас } & \text { чавылдак } & \text { көгү-биле } & \text { тур=бас } \\ \text { время } & \text { время-с } & \text { стоять=NEGPrP } & \text { ирис } & \text { зеленый-с } & \text { стоять=NEGPrP }\end{array}$

Перевод: 'Времена (года) меняются, растения не стоят (всегда) зелеными’.

(3) ... чиңзирти чуглуп, чиңзис чуруп турар шагда-даа чүвең иргин (Аксагалдай ашак: тыва хуулгаазын тоолдар, 1992: 109).

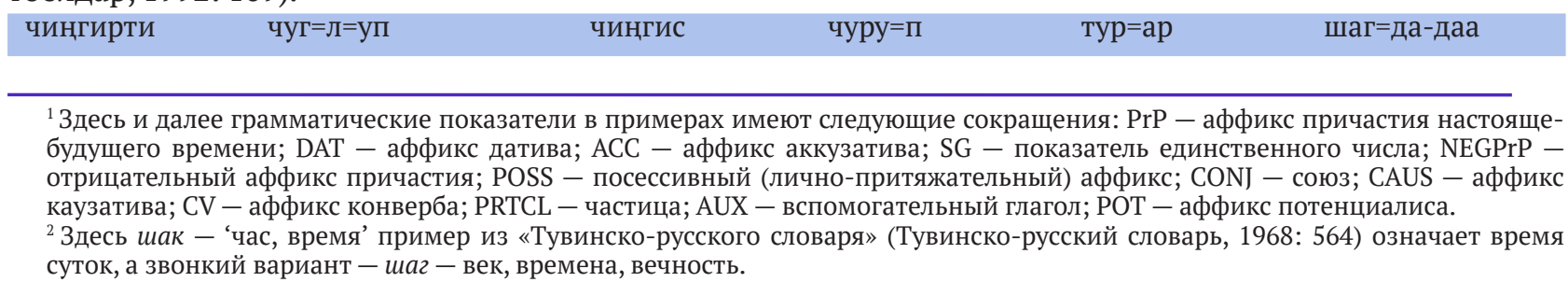


НОВЫЕ ИССЛЕДОВАНИЯ ТУВЫ

Www.nit.tuva.asia

\section{THE NEW RESEARCH OF TUVA}

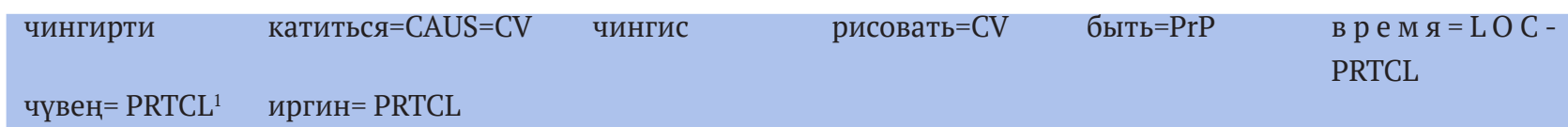

Перевод: ‘Было в то время, когда чингирти каталось, чингис рисовал’ (Букв.: чингирти - катавшееся, чингис - рисовавшее во времена было).

Зачин - начало произведения тувинского народного (фольклорного) творчества (мифов, сказок и т. д.) также характеризуется частым использованием рассматриваемых лексем, усиливающих образное восприятие текста.

4) Шыяан-ам, шаанда шагда чүвең иргин. (Мифы, легенды, предания тувинцев, 2010: 50).

\begin{tabular}{|c|c|c|c|c|}
\hline шыяан-ам & шаанда & шаг=да & чүвең & иргин \\
\hline так.вот & давно & время=LOC & PRTCL & PRTCL \\
\hline
\end{tabular}

Перевод: ‘Так вот, давным давно это было же’.

(5) Биеэде, шаг-шаанда ийи ийис оолдуг Бора хой чоруп тур (Тыва улустуң тоолдары, 2012: 555).

\begin{tabular}{|c|c|c|c|c|c|}
\hline биеэде & шаг-шаанда & ийи & ийис & оол=дуг & бора \\
\hline раньше & время-давно & два & двойня & детеныш=POSSV² & серый \\
\hline хой= овца & чор=уп=жить=CV & тур $=$ AUX & & & \\
\hline
\end{tabular}

Перевод: ‘Раньше, давным-давно жила-была серая овца с двумя двойняшками'.

(6) Эртенгиниң эртезинде, Эңге-тайбың турар шагда (Тыва улустуң тоолдары, 2012: 239).

\begin{tabular}{|c|c|c|c|}
\hline эртенги=ниң & эрте=зи=н=де & эңге-тайбың & тур=ар \\
\hline утренний=GEN ${ }^{3}$ & рано=POSS.3=INFIX=LOC & самый-мирный & быть $=$ PrP \\
\hline
\end{tabular}

шаг=да $=$ время $=\mathrm{LOC}$

Перевод: 'Раньше раннего, тихо-мирно было когда ...'

(7) Шаанда, революция мурнунда, аңаа бай орустар алдын кастырып турган (Тамба, 1984: 184).

$\begin{array}{llllll}\text { шаанда } & \text { революция } & \text { мурнунда } & \text { аңаа } & \text { бай } & \text { орус=тар } \\ \text { давно } & \text { революция } & \text { перед } & \text { там } & \text { богатый } & \text { pyсcкий=PL } \\ \text { алдын } & \text { кас=тыр=ып } & \text { тур=ган } & & & \\ \text { золото } & \text { копать=CAUS=CV } & \mathrm{AUX}=\mathrm{PP} & & \end{array}$

Перевод: ‘Давно перед революцией там зажиточные русские заставляли золото рыть'.

Конец предложения. В самостоятельном употреблении слово шаг - 'время’ может заканчивать повествовательное предложение, реализуя функцию финитного сказуемого. Оно относится ко всему предложению, сказуемое которого выражено причастием будущего времени на = $p$ от глагола тур= 'стоять'. Слово шаг оформлено аффиксом локатива (местного падежа) $=\partial a$.

(8) Те мыйызы дээрге шаштыгып турар шагда. Тевениң чолдак кудуруу черге дөжелип турар шагда (Тыва тоолдар, 1957: 69).

$\begin{array}{lllll}\text { те.мыйызы } & \text { дээр=ге } & \text { шаштыг=ып } & \text { тур=ap } & \text { шаг=да } \\ \text { козлиные рога } & \text { небо=DAT } & \text { упираться=CV } & \text { AUX=PrP } & \text { время=LOC }\end{array}$

\footnotetext{
${ }^{1}$ LOC - аффикс локатива; PRTCL - частица.

${ }^{2} \mathrm{POSSV}$ - форма обладания.

${ }^{3}$ GEN - аффикс генитива; INFIX - морфема, вставляемая перед аффиксом косвенных падежей.
} 


$\begin{array}{lllll}\begin{array}{l}\text { теве=ниң } \\ \text { верблюд=GEN }\end{array} & \begin{array}{l}\text { колдуру=y } \\ \text { короткий }\end{array} & \begin{array}{l}\text { кер=ге } \\ \text { туруру=y }\end{array} & \text { земля=DAT } & \begin{array}{l}\text { дөжел=ип } \\ \text { стлаться=CV }\end{array} \\ \text { AUX=PrP } & \text { шаг=да } & & & \\ \text { время=LOC } & & \end{array}$

Перевод: 'В то время, когда рога козерога доходили до неба. В то время, когда короткий хвост верблюда покрывал землю’.

(9) Дөңгеликтиң бажындан дөрт өң чечек үнүп, Дөңгүр инектиң бажындан мыйыс үнүп турар шагда (Бокту-Кириш, Бора-Шээлей, 1995: 5).

$\begin{array}{llllll}\begin{array}{l}\text { дөңгелик=тиң } \\ \text { кочка=GEN }\end{array} & \text { бажын=дан } & \text { дөрт } & \text { өң } & \text { чечек } & \text { YH=үп } \\ \text { дөңгүр } & \text { макушка=ABL } & \text { четыре } & \text { цвет } & \text { цветок } & \text { всходить=CV } \\ \text { комолый } & \text { корова=GEN } & \text { бажын=дан } & \text { мыйыс } & \text { үн=у } & \text { тур=ар } \\ \text { шаг=да } & & & \text { рог } & \text { вырастать=CV } & \text { AUX=PrP } \\ \text { время=LOC } & & & & & \end{array}$

Перевод: 'В то время, когда на макушке маленького холма расцветали четырехцветные цветочки, в то время, когда вырастали рога у комолой коровы’.

(10) Сүт-Хөл шалбаа, Сүмбер-Уула тей турар шагда (Тыва тоолдар, 2014: 172).

$\begin{array}{llllll}\text { Сүт-Хөл } & \text { шалбаа } & \text { Сүмбер-Уула } & \text { тей } & \text { тур=ap } & \text { шаг=да } \\ \text { Сут-Хол } & \text { лужа } & \text { Сумбер-Уула } & \text { сопка } & \text { AUX=PrP } & \text { время=LOC }\end{array}$

Перевод: ‘Было в то время, когда Сут-Хол было лужицей, Сумбер-Уула была сопкой’.

В данном примере наблюдается групповое оформление именной части двух событий сочетанием турар шагда - 'в то время', имевших место в прошлом.

Служебная функция лексемы шаг. Лексически полнозначные слова, используемые в функции связующего средства (скрепа внутри предложения или между предложениями, союз и т. п.), являются источником новых грамматических показателей.

Для лексемы шаг характерно то, что в служебном (грамматикализованном) использовании, органически сливаясь с падежом и растворяя в чисто грамматических функциях свое лексическое значение, оно превращается в формально грамматический элемент, осложняющий значение падежа особыми, главным образом, пространственными значениями.

Основная функция лексемы шаг в служебном употреблении состоит в формировании причастно-послеложных конструкций сказуемого зависимой ПЕ. Такие конструкции включают в состав показателя связи послелог - лексический носитель выражаемого синтаксического отношения двух предикативных единиц (ПЕ). Это система развивающаяся, и в состав послелогов входят грамматикализовавшиеся лексемы разного характера, прежде всего, имена отношений, находящиеся на разной стадии грамматикализации.

Кроме послелогов, специфику причастно-послеложных конструкций составляют разные причастия, сочетающиеся с одним и тем же послелогом. Конструкции, допускающие варьирование причастных форм при одном послелоге, выражают разные временные значения. Заметим, что существуют особые лексические контексты, в которых активируется аналогия с пространством и временные конструкции начинают вести себя параллельно пространственным.

Рассмотрим случаи со служебным словом шагда - ‘давно', сочетания с которым составляют особую группу темпоральных конструкций с семантикой общей временной соотнесенности.

Своеобразие конструкций этого типа состоит в том, что передается темпоральная семантика с помощью форм имен со значением 'время’: шаанда (шагда), үемде (үеде), өйүнде (өйде). В составе БПК эти своеобразные послелоги не оторвались еще окончательно от именных основ. В них потенциальная позиция

${ }^{1} \mathrm{ABL}$ - аффикс аблатива. 
посессивного аффикса - морфологический признак служебных имен - может оставаться пустой (ср.: шаг $\left.=\partial a ; m a a=M=\partial a ; m a a={ }_{\xi}=\partial a ; m a a=\mu=\partial a\right)$. У служебного имени на месте выпадения сонорного г между гласным основы и аффиксом принадлежности 3-го лица =bl, произошло стяжение и полная ассимиляция гласных и образовался долгий гласный на стыке морфем (Грамматика тувинского языка ..., 1961: 57). Инфикс $=\boldsymbol{H}-$ вставной согласный перед падежным аффиксом.

Сочетаются указанные послелоги не с одной, а с несколькими формами зависимых сказуемых. Чередование причастных форм оказывает влияние на семантику БПК: внутри одного семантического типа темпорального - это значение дифференцируется.

(11) Оларның иштидаштынга чиңгине арыглаашкын кылдыртпаан шаамда амыравас мен (Сарыкай, 1985: 7).

\begin{tabular}{|c|c|c|c|c|}
\hline олар=ның & ишти-дашты=н=га & чиңгине & арыглаашкын & кылдыр=т=па=ан \\
\hline они=GEN & $\begin{array}{l}\text { внутри- } \\
\text { снаружи=INFIX=DAT }\end{array}$ & настоящий & чистка & делать $=\mathrm{CAUS}=\mathrm{NEG}^{1}=\mathrm{PP}^{2}$ \\
\hline шаа=м=да & амыра=вас & мен & & \\
\hline время=1SG=LOC & успокаиваться=NEGPrP & я & & \\
\hline
\end{tabular}

Перевод: ‘Пока я не проведу среди них настоящую чистку, я не успокоюсь'.

В этом примере, сказуемое ЗПЕ, выраженное сочетанием причастия прошедшего времени на =ган в отрицательной форме с послелогом шаамда, передает значение предела во времени 'пока не’.

(12) Мен аныякдаа, күшшыдалдыгдаа, ажылишчидаа чоруур шаамда чүве ийин ол (Тамба, 1984: 141).

$\begin{array}{lllll}\text { мен } & \text { аныяк-даа } & \text { күш- шыдалдыг-даa } & \text { ажыл-ишчи-даa } & \text { чору=ур } \\ \text { я } & \text { молодой-PRTCL } & \text { сильный-PRTCL } & \text { труженик-PRTCL } & \text { быть=PrP } \\ \text { шаа=M=да } & \text { чүве } & \text { ийин } & \text { ол } \\ \text { время=1SG=LOC } & \text { вещь } & \text { PRTCL } & \text { тот }\end{array}$

Перевод: ‘Это было тогда, когда я был молодым, сильным, работягой’.

Здесь рассматриваемый послелог сочетается с формой причастия будущего времени на $=p$. Выражено значение одновременности 'в то время, когда'.

(13) Чогум шаанда, бистиң-даа мурнувуста эрги Тыва үезинде, херээжен кижини кандыг-даа тура-сорук деп чүве барымдаалавас тудуп бериптер чүве дээн (Тамба, 1984: 226).

\begin{tabular}{|c|c|c|c|c|c|}
\hline чогум & шаа=н=да & бис=тиң-даа & мурну $=$ вус $=$ та & эрги & Тыва \\
\hline именно & время=POSS.3=LOC & $\begin{array}{l}\text { мы=GEN- } \\
\text { PRTCL }\end{array}$ & раньше=1PL=LOC & старый & Тыва \\
\hline $\mathrm{Ye}=3 и=\mathrm{H}=$ де & херээжен & кижи=ни & кандыг-даа & $\begin{array}{l}\text { тура- } \\
\text { сорук }\end{array}$ & деп \\
\hline время=POSS.3=INFIX=LOC & женщина & человек=AСС & никакой-PRTCL & $\begin{array}{l}\text { желание- } \\
\text { воля }\end{array}$ & $\mathrm{CONJ}$ \\
\hline чүве & барымдаа=ла=вас & туд=уп & бер=ипт=ер & & \\
\hline дело & основание=VS=NEG & держать=CV & $\mathrm{AUX}=\mathrm{PERFV}=\mathrm{PrP}$ & & \\
\hline чүве= дело & дэ=эн $=$ говорить $=\mathrm{PP}$ & & & & \\
\hline
\end{tabular}

Перевод: 'Говорили, что раньше, когда нас еще не было, в старой Туве женщину выдавали (замуж) без всякого желания’.

\footnotetext{
${ }^{1} \mathrm{NEG}$ - отрицательный аффикс глагола.

${ }^{2} \mathrm{PP}-$ аффикс причастия прошедшего времени.
} 
В этом примере представлено именное сочетание чогум шаa=н=дa - 'именно то время'. В целом данное сочетание вводит тему высказывания, характеризуя ситуацию, имевшую место в далеком прошлом.

(14) Мен ол аалга кадарчылап келген үемде черле ындыг чүве болбаан (Тамба, 1984: 228).

$\begin{array}{llllll}\text { мен } & \text { ол } & \text { аал=га } & \text { кадарчыла=п } & \text { кел=ген } & \text { үe=M=де } \\ \text { я } & \text { тот } & \text { аал=DAT } & \text { работать.пастухом=CV } & \text { AUX=PP } & \text { время=1SG=LOC } \\ \text { черле } & \text { ындыг } & \text { чүве } & \text { бол=ба=ан } & \\ \text { вовсе } & \text { такой } & \text { вещь } & \text { быть=NEG=PP } & \end{array}$

Перевод: ‘В то время, когда я работал пастухом в этом аале, такого вовсе не было’.

Сделанные нами выводы не противоречат результатам, полученным другими исследователями. Например, А. А. Пальмбах, Ф. Г. Исхаков (Исхаков, Пальмбах, 1961: 439), М. В. Оюн (Оюн, 1988), говоря о самостоятельности служебных имен в фонетическом отношении, подчеркивают их формальную функцию в качестве маркеров пространственных падежей с дополнительной смысловой нагрузкой. Рассмотренные нами примеры с послелогами (шаанда, үеде), сохраняющими пока тесную связь с именами, от которых они образовались, подтверждают это наблюдение исследователей тувинского языка.

\section{Заключение}

Проведенное исследование позволяет сделать следующие выводы. Во-первых, выявлена структура, отражены семантика и функционирование морфосинтаксических конструкций, которые получают новую интерпретацию в условиях культурной адаптации, обеспечивающей выполнение ими вновь возникающих функций.

Во-вторых, установлено, что выявленные грамматикализованные причастно-послеложные конструкции с темпоральными лексемами шаг - 'время', үе - 'время' представляют регулярно воспроизводимые инновационные структуры, оформляющие либо зачала, либо концовки предложения. Лексема шаг функционирует, наряду с глагольными авторизаторами источника информации бодаарга, минниирге, болза, дээрге, как устойчивый лексический стандарт, обеспечивающий новое коммуникативное применение в условиях фольклорного контекста.

Кроме того, лексема шаг, занимая разные позиции в структуре предложения, функционирует как: 1) скрепа; 2) член предложения с семантикой обстоятельства времени с именными определениями, 3) определение в зависимой ПЕ.

Тувинский язык выработал особые языковые средства выразительности, характерные для текстов определенного дискурса. Любому связному событийному тексту в совокупности с различными жизненными, социокультурными, психологическими и др. факторами присущи собственный набор стандартных фраз и собственное лексическое наполнение, зависящее, в том числе, и от культурных традиций народа.

Автор считает, что обозначенные в статье проблемы, требуют специального исследования структуры, семантики и функционирования грамматикализованных структур, создания классификационных схем для таких языковых единиц в тувиноведении. Результаты исследования вносят вклад в развитие теории грамматикализации, вписывая материалы тувинского языка в группу языков, в которых данное явление уже получило научную интерпретацию и широко изучено.

\section{СПИСОК ЛИТЕРАТУРЫ}

Аксагалдай ашак: тыва хуулгаазын тоолдар [Старик Аксагалдай. Тувинские волшебные сказки] (1992) / сост. 3. Б. Самдан. Кызыл: Тываның ном үндүрер чери. Т. 1. 220 арын. (На тув. яз.)

Алдай-Буучу: Тыва улустуң маадырлыг тоолдары [Героические сказания тувинского народа] (1993) / сост. С. М. Орус-оол. Кызыл : Тываның ном үндүрер чери. Т. II. 288 арын. (На тув. яз.).

Аналитические конструкции в языках различных типов (1965) / ред. В. М. Жирмунский, О. П. Суник. М. ; Л. : Наука. 343 с. 
Арутюнова, Н. Д. (1976) Предложение и его смысл: Логико-семантические проблемы. М. : Наука. 383 с.

Белошапкова, В.А. (1977) Современный русский язык. Синтаксис. М. : Высшая школа. 247 с.

Бокту-Кириш, Бора-Шээлей: Тыва улустуң маадырлыг толу [Тувинский народный эпос] (1995) / сост. С. М. Орус-оол. Кызыл : Тываның ном үндүрер чери. , IV том 224 арын. (На тув. яз.)

Гивон, Т. (2015) Сложность и развитие // Язык и мысль / отв. ред. А. А. Кибрик. М. : Языки славянской культуры. 843 c. C. $89-122$.

Гращенков, П. В. (2015) Тюркские конвербы и сериализация. Синтаксис, семантика, грамматикализация. М. : Языки славянской культуры. 264 с.

Даржай, А. (1994) Душтук дүнү [Ночь невесты] // Улуг-Хем (альманах). № 5. Кызыл : Тываның ном үндүрер чери. 159 арын. А. 3-22 (На тув. яз.).

Исхаков, Ф. Г., Пальмбах А. А. (1961) Грамматика тувинского языка. Фонетика и морфология. М. : Издательство восточной литературы. 470 с.

Касевич, В. Б (1988) Семантика. Синтаксис. Морфология. М. : Наука. 320 с.

Курилович, Е. (1965) О методах внутренней реконструкции // Новое в лингвистике. Вып. 4. М. : Прогресс. 592 с. C. 400-433.

Майсак, Т. А. (2005) Типология грамматикализации конструкций с глаголами движения и глаголами позиции. М. : Языки славянских культур. 480 с.

Мифы, легенды, предания тувинцев (2010) // Памятники фольклора народов Сибири и Дальнего Востока / отв. ред. В. В. Илларионов. Новосибирск : Наука. Т. 28. 371 с. (На тув. яз.).

Монгуш, Д. А. (1963) Формы прошедшего времени изъявительного наклонения в тувинском языке. Кызыл : Тувинское книжное издательство. 167 с.

Оюн, М. В. (1988) Определительные конструкции в тувинском языке : автореф. дисс. ... канд. филол. н. Алма-Ата. 19 c.

Предикативное склонение причастий в алтайских языках (1984) / отв. ред Е. И. Убрятова, Ф. А. Литвин. Новосибирск : Наука. 192 с.

Плунгян, В. А. (2011) Ю. Д. Апресян как теоретик Грамматики конструкций // Слово и язык / отв. ред. Е. В. Рахилина. М. : Языки славянских культур. 736 с. С. 548-557.

Русская грамматика (1980) : в 2 т. / отв. ред. Н. Ю. Шведова. М. : Наука. Т. 2. Синтаксис. 709 с.

Сат, Ш. Ч. (1955) Тувинский язык (грамматический очерк) // Тувинско-русский словарь / отв. ред. А. А. Пальмбах. М. : Государственное издательство иностранных и национальных словарей. 724 с. С. 615-721.

Сарыкай, Д. (1985) Буураашкын // Улуг-Хем (альманах). № 61. Кызыл: Тувинское книжное издательство. 160 с. С. 3-31. (На тув. яз.)

Структурные типы синтетических полипредикативных конструкций в языках разных систем (1986) / отв. ред. Е. И. Убрятова, Ф. А. Литвин. Новосибирск : Наука. 320 с.

Тамба С. (1984) Үелерниң үскүлежии [Столкновение времен]. Кызыл : Тываның ном үндүрер чери. 256 арын. (На тув. яз.)

Тестелец, Я. Г. (2001) Введение в общий синтаксис. М. : Издательский центр РГГУ. 798 с.

Тувинско-русский словарь (1968) / отв. ред. Э. Р. Тенишев. М. : Советская энциклопедия. 646 с.

Тыва тоолдар (2014) : О. К.-Ч. Дарыманың чыып бижээн материалдары [Тувинские сказки. Материалы, собранные О. К. Дарымой] / сост. С. М. Орус-оол, М. Б. Кунгаа. Кызыл: Тываның ном үндүрер чери. 234 арын. (На тув. яз.)

Тыва тоолдар [Тувинские сказки] (1957). Кызыл : Тываның ном үндүрер чери. T. IV. 183 арын с. (На тув. яз.)

Тыва улустуң тоолдары (2012): Тываның тоолчуларының II дугаар следунуң материалдары [Тувинские народные сказки: Материалы II слета сказителей Тувы] / сост. С. М. Орус-оол. Кызыл : Тываның ном үндүрер чери. 405 арын. (На тув. яз.).

Тыва маадырлыг тоолдар [Тувинские героические сказания] (1990) / сост. С. М. Орус-оол. Кызыл : Тываның ном үндүрер чери. 272 арын. (На тув. яз.).

Черемисина, М. И. (1979) Некоторые вопросы теории сложного предложения в языках разных систем. Новосибирск: Издательство НГУ. 82 с.

Шамина, Л. А. (2016) Грамматикализация глаголов «смены собственника в тувинском языке» // Международный научно-исследовательский журнал. № 12 (54). Ч. 2. С. 91-93.

Шведова, Н. Ю. (1960) Очерки по синтаксису русской разговорной речи. М. : Изд-во Акад. наук СССР. 378 с. 


\section{REFERENCES}

Aksagaldai ashak: tyva khuulgaazyn tooldar [Old Aksagaldai. Tuvan fairy tales] (1992) / comp. by Z. B. Samdan. Kyzyl, Tuvan book publ. Vol. 1.220 p. (In Tuv.)

Aldai-Buuchu: Tyva ulustung maadyrlyg tooldary [Heroic legends of the Tuvan people] (1993) / comp. by S. M. Orus-ool. Kyzyl, Tuvan book publ. Vol. II. 288 p. (In Tuv.)

Analiticheskie konstruktsii v iazykakh razlichnykh tipov [Analytical constructions in languages of various types] (1965) / ed. by V. M. Zhirmunskii and O. P. Sunik. Moscow, Leningrad, Nauka. 343 p. (In Russ.).

Arutiunova, N. D. (1976) Predlozhenie i ego smysl: Logiko-semanticheskie problem [The sentence and its sense: Logical and semantic issues]. Moscow, Nauka. 383 p. (In Russ.).

Beloshapkova, V. A. (1977) Sovremennyi russkii iazyk. Sintaksis [Modern Russian language: Syntax]. Moscow, Vysshaia shkola. 247 p. (In Russ.).

Boktu-Kirish, Bora-Sheelei: Tyva ulustung maadyrlyg tolu [Boktu-Kirish, Bora-Seelei: a Tuvan folk epic] (1995) / comp. by S. M. Orus-ool. Kyzyl, Tuvan book publ. Vol. IV. 224 p. (In Tuv.).

Givon, T. (2015) Slozhnost' i razvitie [Complexity and development]. In: Iazyk i mysl' [Language and thought] / ed. by A. A. Kibrik. Moscow, Iazyki slavianskoi kul'tury. 843 p. Pp. 89-122. (In Russ.).

Grashchenkov, P. V. (2015) Tiurkskie konverby i serializatsiia. Sintaksis, semantika, grammatikalizatsiia [Turkic converbs and serialization. Syntax, semantics, grammaticalization]. Moscow, Iazyki slavianskoi kul'tury. 264 p. (In Russ.).

Darzhai, A. (1994) Dushtuk dünü [Night of the bride]. Ulug-Khem (almanac), no. 5. Kyzyl, Tuvan book publ. 159 p. Pp. 3-22 (In Tuv.).

Iskhakov, F. G. and Pal'mbakh A. A. (1961) Grammatika tuvinskogo iazyka. Fonetika i morfologiia [A grammar of Tuvan language. Phonetics and morphology]. Moscow, Izdatel'stvo vostochnoi literatury. 470 p. (In Russ.).

Kasevich, V. B (1988) Semantika. Sintaksis. Morfologiia [Semantics. Syntax. Morphology]. Moscow, Nauka. 320 p. (In Russ.).

Kurilovich, E. (1965) O metodakh vnutrennei rekonstruktsii [On methods of internal reconstruction]. In: Novoe v lingvistike [Advances in linguistics]. Vol. 4. Moscow, Progress. 592 p. Pp. 400-433. (In Russ.).

Maisak, T. A. (2005) Tipologiia grammatikalizatsii konstruktsii s glagolami dvizheniia i glagolami pozitsii [Typology of grammaticalization of constructions with verbs of motion and verbs of position]. Moscow, Iazyki slavianskikh kul'tur. $480 \mathrm{p}$. (In Russ.).

Mify, legendy, predaniia tuvintsev [Myths and legends of Tuvans] (2010). In: Pamiatniki fol'klora narodov Sibiri i Dal'nego Vostoka [Monuments of folklore of the peoples of Siberia and the Far East] / ed. by V. V. Illarionov. Novosibirsk, Nauka. Vol. 28. 371 p. (In Tuv.).

Mongush, D. A. (1963) Formy proshedshego vremeni iz"iavitel'nogo nakloneniia v tuvinskom iazyke [Forms of the past tense of the indicative mood in the Tuvan language]. Kyzyl, Tuvan book publ. 167 p. (In Russ.).

Oyun, M. V. (1988) Opredelitel'nye konstruktsii v tuvinskom iazyke [Definitive constructions in the Tuvan language] : Thesis of Diss.... Candidate of Philology. Alma-Ata. 19 p. (In Russ.).

Predikativnoe sklonenie prichastii $v$ altaiskikh iazykakh [Predicative declension of participles in Altaic languages] (1984) / ed by E. I. Ubriatova and F. A. Litvin. Novosibirsk, Nauka. 192 p. (In Russ.).

Plungian, V. A. (2011) Yu. D. Apresian kak teoretik Grammatiki konstruktsii [Yu. D. Apresyan as a theorist of grammar constructions]. In: Slovo i iazyk [The word and the language] / ed. by E. V. Rakhilina. Moscow, Iazyki slavianskikh kul'tur. 736 p. Pp. 548-557. (In Russ.).

Russkaia grammatika [A grammar of Russian language] (1980) : in 2 vol. / ed. by N. Yu. Shvedova. Moscow, Nauka. Vol. 2. Sintaksis. 709 p. (In Russ.).

Sat, Sh. Ch. (1955) Tuvinskii iazyk (grammaticheskii ocherk) [Tuvan language: a grammar sketch]. In: Tuvinskorusskii slovar' [A Tuvan-Russian dictionary] / ed. by A. A. Pal'mbakh. Moscow, Gosudarstvennoe izdatel'stvo inostrannykh i natsional'nykh slovarei. 724 p. Pp. 615-721. (In Russ.).

Sarykai, D. (1985) Buuraashkyn. Ulug-Khem (almanac), no. 61. Kyzyl, Tuvan book publ. 160 p. Pp. 3-31. (In Tuv.).

Strukturnye tipy sinteticheskikh polipredikativnykh konstruktsii $v$ iazykakh raznykh sistem [Structural types of synthetic polypredicative constructions in languages of various systems] (1986) / ed. by E. I. Ubriatova and F. A. Litvin. Novosibirsk, Nauka. 320 p. (In Russ.).

Tamba S. (1984) Yelerning üskülezhii [Collision of temps]. Kyzyl, Tuvan book publ. 256 p. (In Tuv.)

Testelets, Ia. G. (2001) Vvedenie v obshchii sintaksis [An introduction to general syntax]. Moscow, Publishing center RGGU. 798 p. (In Russ.).

Tuvinsko-russkii slovar' [A Tuvan-Russian dictionary] (1968) / ed. by E. R. Tenishev. Moscow, Sovetskaia entsiklopediia. 646 p. (In Russ.).

Tyva tooldar : O. K.-Ch. Darymanyng chyyp bizheen materialdary [Tuvan tales. Materials collected by O. K. Daryma] (2014) / comp. by S. M. Orus-ool and M. B. Kungaa. Kyzyl, Tuvan book publ. 234 p. (In Tuv.)

Tyva tooldar [Tuvan tales] (1957). Kyzyl, Tuvan book publ. Vol. IV. 183 p. (In Tuv.) 
Tyva ulustung tooldary : Tyvanyng toolchularynyng II dugaar sledunung materialdary [Tuvan folk tales: Materials of the 2nd gathering of the storytellers of Tuva] (2012)/ comp. by S. M. Orus-ool. Kyzyl, Tuvan book publ. 405 p. (In Tuv.).

Tyva maadyrlyg tooldar [Tuvan heroic tales] (1990) / comp. by S. M. Orus-ool. Kyzyl, Tuvan book publ. 272 p. (In Tuv.).

Cheremisina, M. I. (1979) Nekotorye voprosy teorii slozhnogo predlozheniia viazykakh raznykh system [Some issues of complex sentence theory in languages of different systems]. Novosibirsk, NGU Publ. 82 p. (In Russ.).

Shamina, L. A. (2016) Grammatikalizatsiia glagolov «smeny sobstvennika v tuvinskom iazyke» [Grammaticalization of verbs of change of ownership in the Tuvan language]. Mezhdunarodnyi nauchno-issledovatel'skii zhurnal, no. 12 (54), part 2, pp. 91-93. (In Russ.).

Shvedova, N. Iu. (1960) Ocherki po sintaksisu russkoi razgovornoi rechi [Essays on the syntax of Russian colloquial speech]. Moscow, Akad. nauk SSSR Publ. 378 p. (In Russ.).

Submission date: 30.01.2019. 